\title{
Teachers in Film: Inspiration for Autonomous and Transformative Teaching or a Warning against It?
}

\author{
Orit Schwarz-Franco
}

Department of Teacher Education, Hebrew University of Jerusalem, Israel

Copyright $\bigcirc 2016$ by authors, all rights reserved. Authors agree that this article remains permanently open access under the terms of the Creative Commons Attribution License 4.0 International License

\begin{abstract}
Can teachers promote a change? Are teachers free in their work? In the first part of this article I present a theoretical answer to these two questions and show the relation between them, based on the theories of two thinkers. Paulo Freire and Joseph Schwab teach us that teachers are autonomous and that they can lead processes of change in the school system as well as in society. Films about teachers can inspire teachers to dare to use the freedom they have in class and to be promoters of change. On the other hand, the same movies may also instill in teachers doubts regarding their own competence to create change and fears of the outcomes of such a change. In the second part of the article, I raise awareness of the various overt and elusive messages present in movies about teachers, I discuss several examples, and I suggest a few warnings and recommendations regarding how teacher education programs might approach and utilize films about teachers so as to support the teachers' self-image as autonomous and capable of social transformation.
\end{abstract}

Keywords Freire, Schwab, Teachers in Films, Autonomy of Teachers

\section{Introduction}

Can teachers promote a change - in their students, in the education system, and in society at large? Are teachers autonomous in their work? Indeed, these questions are interconnected. In the first part of this Article, I present a theoretical answer to these two questions and show the relation between them, based on the theories of two thinkers: Paulo Freire (1921-1997) and Josef Schwab (1909-1988).

Following the theoretical discussion, I address more practical questions: do teachers perceive of themselves - and does society perceive of them - as being capable of making a change? Are teachers thought of as free and autonomous? Are they encouraged to be so? I address these questions through the prism of movies about teachers, which provide a useful reflection on the image of teachers and teaching. In the second part of the article, I raise awareness of the various overt and elusive messages present in movies about teachers, I discuss several examples, and I suggest a few warnings and recommendations regarding how teacher education programs might approach and utilize films about teachers so as to support the teachers' self-image as autonomous and capable of social transformation.

\section{Part I: Autonomous and Transformative Teaching}

In this part I very briefly present Schwab's theory of autonomous teaching and Freire's theory of dialogical pedagogy. I then proceed to demonstrate the interrelation between the issues of autonomy in teachers' work and teachers' capability to promote change.

\section{Autonomous Teaching}

Do teachers have the freedom to decide about essential aspects of their work? Schwab's answer is yes, teachers are free; for him, this is both a descriptive statement and a prescriptive one.

First, Schwab [11] defines the work of teachers as a 'practical art.' Teaching is an art because it is an activity that does not fall under fixed rules, it is constantly dynamic, and it demands creativity; more specifically, it is a practical art because teaching situations are always concrete ones in which teachers must act and react to the complexity of circumstances. ${ }^{1}$

In order to further elaborate on the characteristics of a practical rather than a theoretical domain, Schwab [11] discusses the essential differences between theory and practice (p. 107-110). A theory is narrow by definition; it looks at one aspect of the subject, observing it only from one point of view. On the other hand, a theory is abstract and general, because it ignores all the details of the concrete circumstances. In contrast, a practical situation is always complex, rich with specific details; moreover, it involves

1Schwab adopts here Dewey's term of a 'problematic situation' as the basic unit of human thinking [3]. 
multiple aspects that may be seen from various vantage points. Therefore, different theories can support different aspects of a practical decision, but no single theory can ever cover the totality of the situation or offer a complete solution to a practical problem.

Therefore, Schwab [11] claims that good teachers must master a set of practical arts that include the ability to apply a general theory to a concrete situation, and the "art of the eclectic", which enables one to intertwine various theories while acknowledging the incompleteness of each and every one of them (pp. 111-116). These ideas are presented in the first article named "the practical"; they are further elaborated in three consequent articles that were ultimately comprised into "the project of the practical" (1969[11], 1971 [12], 1973[13], 1983[14]).

The arts are based on a certain conception that recognizes knowledge as a human creation and not as a set of facts given to us from an objective source. Schwab's epistemology may be identified with the philosophical concession on the possibility of attaining an absolute truth, as well as with the acceptance of the subjective and interpretive nature of human knowledge. ([12] pp. 495-498)

Schwab shows this conception of knowledge to be connected to a key characteristic of the schoolteacher's mission: the ability to perceive every educational situation from different points of view simultaneously. This complexity in the teacher's decision-making process stresses the impossibility of controlling these decisions from the outside, by any set of rules or commands that exist prior to the concrete educational situation. On these grounds, Schwab shows that teachers are necessarily and unavoidable autonomous in their work: "Teachers will not and cannot simply be told what to do. Teachers are not assembly line operators and will not so behave" (Schwab [14] p. 245). Schwab clarifies that teachers' freedom does not necessarily entail a rebellious attitude or a nonconformist approach. Their freedom is simply forced on them by the constant need to interpret their general instructions and adapt them to the endlessly complex concrete situation in class. This is Schwab's descriptive statement.

The prescriptive statement that follows is that a teacher's freedom must be respected. Schwab calls for greater involvement of teachers in processes of pedagogical planning and decision making, such as the curricular committees that he suggests to create in every school (Schwab [14] pp. 244-250). Notably, he claims that curricular planning must always take into consideration four 'commonplaces' of education: the pupil, teacher, learning material, and social milieu([13] pp. 502-503). Furthermore, Schwab stresses the importance of balancing these four aspects and encourages teamwork and proper communication between the representatives of the four aspects. Above all, he emphasizes the priority of teachers as curricular planners and explaining this priority as follows:

There are two major reasons for this emphasis. First, the children of the school as learners: their behavior and misbehavior... what raises hopes, fears and despair in respect to learning... what they disdain, what they see as relevant to their present or future lives... are better known to no one but the teacher. It is he who tries to teach them. It is she who lives with them for the better part of the day and the better part of the year ([14] p. 245).

As such, teachers' involvement in decision making is appropriate because they know the pupils, who are placed at the center of pedagogical thinking. ${ }^{2}$ Schwab then adds another justification for teachers' necessary autonomy, arguing that teachers' involvement in curricular planning...:

...creates the only language in which knowledge adequate to an art can arise. Without such knowledge, teachers not only feel decisions as impositions, they find that intelligence cannot traverse the gap between the generality of merely expounded instructions and the particularities of teaching moments ([14] p. 246).

Thus, teachers' involvement in decision making intensifies their ability, willingness, and motivation in applying the decisions. Enabling teachers to actively participate in designing the curriculum they teach yields better harmony between the general guidelines of curriculum and the multiple choices they make in their work. Respecting teachers' autonomy in formal and systematical ways suits the autonomy that they necessarily apply in class anyway.

Thomas Robby [9], who had studied and worked with Schwab, offers a retrospective view on Schwab's work, in an article who examines Schwab's influence, forty years after the publication of "Practical 1" [11]. Robby discusses the educational domains that were changed, and those who were not sufficiently influenced to his opinion. On one hand he suggests that: "Schwab's critique legitimized many practical orientations not before possible. The field is definitely more pluralistic"([9] p. 87). On the other hand he admits: "There has been no systematic exploitation of Schwab's total vision for education, and now he is fading as the most over quoted but underused footnote in the research literature" ([9] p.88).To conclude he describes Schwab's attitude as an inspiration for educators to adopt a critical stance, not just as a theoretical view, but as a source of motivation for creating change: "Schwab rejects the "tragic view" of educational failures, regarding them as opportunities to do better. He believes in reform, while never ceasing to criticize when and where it falls short. Practical 1 is not a screed, but an invitation to dialogue, collaborate, and improve. This optimistic view is central to all his work and is how his thinking can help us embrace the ongoing life of education."([9] p. 88).

2 Here too, we recognize Dewey's influence on Schwab's thinking, concerning paidocentric pedagogy. 


\section{Transformative Teaching}

Paulo Freire encourages teachers to empower their students through dialogic pedagogy, thereby creating political change. First, he argues that education is always political, and can never be politically or morally neutral ([6] p. 12). Evidently, curricular contents are chosen with political considerations and express the values and perspectives of the decision makers. Furthermore, Freire explains that even the methods of teaching and the behavior of teachers and pupils in class express and enforce certain political choices: a teacher who lectures and expects her pupils to quietly write down her exact words is promoting values of obedience and total acceptance of authoritative power without doubt or criticism. In contrast, the dialogic teacher that Freire prefers holds class discussions and invites the pupils to actively participate in dialogic learning.

Moreover, dialogic pedagogy includes critical reading of texts and critical analysis of the social and cultural conditions of the pupils' lives. The dialogic teacher may even encourage the pupils to participate in designing the course's curriculum and in choosing the subjects to be studied. This pedagogy is political, as it encourages pupils to be active participants and critical social and political transformers([6] pp. 10-14).

A central assumption underlying dialogic pedagogy is that learning is not and should not be merely the "passing" of knowledge, created elsewhere, from the teacher to the pupils. As opposed to the 'banking method' based on 'depositing' information in the pupils' minds(which is what Freire suggests happens in traditional schools), Freire stresses that the process of learning is connected to the process of research in whereby knowledge evolves. Thus, he considers the class to be where knowledge is created and recreated, in a permanently dynamic process.

We may recognize here again the epistemological approach that denies the unity of knowledge as a static body of facts, containing the single truth about reality, but rather identifies knowledge as the dynamic flow of human interpretations. The teacher is thus defined as a researcher or even in Freire's definition an artist -given the creativity teaching requires and the aesthetic and dramatic aspects of teaching ([6] pp. 115-116). Notably, the objection to authoritative truth leads to educational and political objections to authoritative pedagogy and authoritative politics.

Furthermore, Freire discusses 'situated pedagogy,' whereby pupils bring issues from their lives into the classroom, which are combined into the contents being studied ([6] pp. 103-114), enabling space for expression of pupils' attitudes and approaches. Indeed, Freire stresses the importance of acquiring the ability and habit of critically assessing pupil's present assumptions and views, rather than treating them necessarily as truths. Freire [7] uses the term 'concientization' to describe the educational work through which hidden interest and agendas are exposed and people are led to critical consciousness of their social reality.
Notably, Freire objects to the popular understanding of his pedagogy as "open education" that gives up on academic efforts or social and moral commitment. On the contrary, he stresses the rigorous demand of dialogic pedagogy, which requires profound, active involvement in the issues inquired into or the texts read in class. Thus, dialogic pedagogy is transformative because it empowers pupils, providing them the motivation, courage and tools to transform their societies.

Interestingly even today, nearly fifty years after Freire's "classic" work about critical pedagogy [5], Freire is still read as a source of inspiration for educators who are committed to social change. The following are just a few examples of issues and notions that apply Freire's pedagogy as foundations for transformative education in various domains: eco-pedagogy [1], adult education[2], transforming communities through sports education [16], and empowering students through theater and through art [8].

\section{Autonomous Teaching as Transformative}

This brief presentation of Schwab and Freire's basic theories reveals the interesting relations between their messages. Primarily, we can recognize casual relations between the teacher's autonomy, which Schwab stresses, and the teacher's ability to promote change, which Freire emphasizes. The ability to perform dialogic pedagogy, as Freire presents it, depends on the teacher's freedom to make choices and not to be limited by a fixed curriculum. This is a very simple relation revealed by common sense: for example, a teacher who adopts Freire's 'situational pedagogy' and choses to base her course curriculum on issues from her pupils' lives cannot, by definition, receive this curriculum in advance from the education system authorities.

Moreover, these two thinkers share parallel lines of thought and basic principles. First, both scholars accept similar epistemological assumptions regarding knowledge as dynamic, subjective, and interpretive. ${ }^{3}$ Second, on the basis of these assumptions, both scholars characterize teaching as a creative and innovative activity. With this theory of knowledge and these conceptions of teaching in mind, we can justify teachers' autonomy as a necessary condition immanent to their role and their missions as promoters of change.

In other words, I suggest that autonomous and transformative teaching are both dependent on the idea that knowledge is dynamically produced in class and that teaching is a creative undertaking. I will explain this conclusion by negation: if the teacher's role is merely to transmit to passive pupils, ready-made knowledge that was created elsewhere, then it is neither a role that requires autonomy nor one that permits social change. The traditional

3 Never the less, neither of these scholars is a postmodernist or relativist concerning the ability and the importance of social values and educational goals. Rather, their writings reflect mutual commitment to humanist fundaments such as respect for individual autonomy and social responsibility. . 
teacher passively follows a curriculum that was prepared for her by disciplinary experts, while nourishing in her students habits and behaviors that will secure the present social order and prevent change. If, on the contrary, teaching is an active and creative process in which teachers and pupils create knowledge jointly, then teachers must be free to improvise, and pupils are encouraged to change.

Villacañas [17] stresses an aspect of Freire's work that clarifies another way in which Freiere and Schwab are interrelated. He argues against the tendency of education scholars to emphasize the ethical component of Freire's project. Rather, he explains that educational goals like dialogue, equality, freedom, and tolerance should not be treated as abstract ethical values that are universally valid regardless of the social, political and economic circumstances in which people are situated. Instead, Villacañas suggests that according to Freire, these goals should be central to teacher's work on account of their educational efficiency vis-a-vis the specific pedagogical problems posed by circumstances. This interpretation of Freire's concept of teaching stresses the concrete, local, and practical aspects of teaching, much aligned with the characterization Schwab assigns to the profession.

Yet I note one additional way to conceive of the autonomy and transformative role of teachers as interrelated. Namely, only teachers who act as free agents in the schools and classes in which they teach can become role models for the pupils and can offer them a positive personal example of the courage and commitment that enables one to change the world.

\section{Part II: Teachers in Film}

Many movies present teachers as autonomous pioneers of transformation - indeed, almost magicians. The character of the teacher-heroine makes brave decisions and inspires change in her pupils, society, the education system, and the world at large. Watching films about teachers may inspire and encourage education students or beginner teachers; such movies enable emotional identification, expose difficulties, enhance reflection, and engage fruitful discussion. The films may serve as an excellent tool to enhance in teachers the conceptions of autonomous and transformative teaching as Freire and Schwab portray it.

Nonetheless, films about teachers also reflect and enforce society's dual attitude towards the school-teaching profession. On the one hand, teaching is presented as a social mission, a valuable choice worthy of moral appreciation. On the other hand, even the most optimistic films expose teachers' low status and the disrespect they receive from pupils, parents, the educational system itself, and the academic world. Moreover, many of the movies send ambivalent messages concerning teachers' image as independent promoters of change. Indeed, some films express conservative attitudes - both explicitly articulated by some of the characters, and as a hidden agenda delivered through motives in the plot and other means of cinematic expression. Therefore, an uncritical viewing might yield assimilation of negative attitudes regarding the teaching profession, which may substantially obstruct the process by which beginner teachers form their professional identity.

In this Part, I exemplify the complex and ambivalent messages related in films about teachers by discussing a few select examples of motives that I find to be present in many movies. I classify the examples into three 'genres': 'pedagogic tragedies, "pedagogic tales and legends,' and 'pedagogical action movies.'

\section{Pedagogic Tragedies}

Many films present the teacher as a tragic hero: the person who turns to teaching not of her own free will but rather from lack of choice and pays a severe price for this decision. In some films (e.g., To Sir with Love,[1] ), the teacher did not desire this profession but was forced to teach after failing in other fields. Of course, this idea exists not only in films; it is reflected in the popular saying: "those who know - do, and those who don't know - teach. "When films portray teachers as 'losers 'who do not identify with their work, this message may be reinforced.

Moreover, such movies may yield additional possible influences. Watching the unmotivated teacher in the film might give the teachers in the audience an experience of catharsis - an opportunity to unload the frustration and ambivalent feelings they have about their work. Alternately, such films may provide an opportunity to consider the teacher's lack of motivation as a problem that challenges the viewer and calls upon her to react, to differentiate herself from the on-screen anti-hero, and to create a solution.

Never the less, the teacher's life is shown to be hard and miserable. Teachers in films are usually lonely people single, separated (e.g., Educating Rita,[19] , Dead Poets Society, [20]), or widowed(e.g., Good Will Hunting [22],La Lengua de las Mariposas[23]), and if they are not soat the beginning of the film, they become so at some point, when their devotion to the intensive work they do drives their partner away (e.g., Freedom Writers[27]). The teacher is symbolically presented as a monk or a nun, consistent with the historical tradition of schools in Europe that were run by monasteries. Moreover, alongside teachers' emotional and sexual seclusion comes economic humility. It is a well-known fact that teachers in many countries do not earn much; but some films accentuate this situation to the absurd, whereby teachers take on two other jobs in order to finance the 'hobby' of teaching(e.g., Freedom Writers [27]). Absurd or not, the phenomenon of teachers working another job so as to 'make ends meet 'appears not only in fiction movies but also in recent American documentaries that expose teachers' hard work(American Teacher, [29]Teach [30]).

As is generally the case in the tragedy genre, eventually someone dies. Many pedagogic tragedies present a teacher who attempts to perform with the students a dangerous process of pedagogical, moral, or political change, venturing against social norms and values. Some of these attempts end 
tragically when the teacher, a student, or both lose their lives as a result of this pedagogic attempt.

The well-known film Dead Poets Society [20] takes place at a prestigious boarding school in the United States in the 1950s. Mr. Kitting, the literature teacher, encourages his students to rebel against the competitive and conservative institute to which they belong, to focus on the pleasures and experiences of the 'here and now,' and to fulfill their artistic and creative tendencies. In his literature classes, he invites them to rip out academic parts of their books, to bring poetry materials from their personal lives, and to stand on the tables in order to acquire new points of view on situations.

Mr. Kitting reflects a perfect example of a teacher fulfilling Schwab's ideal of autonomy: changing ways of interpreting and applying the curriculum, recognizing personal needs and tendencies of the pupils, and reacting to them. He also reflects Freire's dialogic teacher who exercises situated pedagogy, invites the students' lives into the classroom, and enhances critical understanding of their circumstances.

Indeed, Mr. Kitting creates a change in a few students. One of them choses to participate in a theater group against his father's orders. The father reacts firmly and threatens to send the boy to a military boarding school, leading the boy to collapse under contradictory forces and commit suicide. In the suicidal scene, the boy wears a wreath of thorns and takes the image of Jesus Christ, sacrificing himself on the altar of pedagogic reform.

After the boy's death, the question of responsibility for his death arises explicitly: the school administration blames the teacher, while the pupils are torn between the school's demand to blame him and the emotional connection and commitment they have to their hero. Indeed, the film's message is controversial. When watching it with education students and teachers, I encounter various responses. Some claim that the film presents the teacher as a hero offering reform within a conservative and repressive society that is not ready to accept it. This interpretation attributes responsibility for the boy's death to the father and the school, and not to the teacher, and conceives the boy's death as a sad but necessary price of the social change. This is a reasonable interpretation, but I believe the film to be a reactionary work that sends a severe warning to teachers: beware of making changes and of encouraging pupils to contradict norms because they may pay a high personal price for your 'experiments.'

A recent Film looks at a teacher who puts his students in risk from a different angel. Whiplash [31] shows a violent drum teacher who abuses his students and hurts them both physically and emotionally. This teacher believes that excellence comes out of suffering, and pushes his student to the edge, knowing that they might break, but promising them real artistic success if they don't. The issue of suicide is hinted here too, as we hear of the teacher's former student who couldn't deal with his pressure and had killed himself. As opposed to him, the present student almost breaks, but eventually finds inner forces to overcome the teacher's challenging attitude. As viewers we are left with the doubt whether the personal and emotional price the student pays is worth it, and is this sort of teaching legitimate at all.

The Spanish film La Lengua de las Mariposas[23] takes place right before the Spanish Civil War. Don Gregorio, An elderly teacher, tries to educate his pupils with atheistic and humanistic values and to nourish in them love for nature and mankind. He exercises an unauthoritative pedagogy that focuses on humanistic subjects such as literature and fine arts. Don Gregorio's values and approaches are very different from the violent nationalistic and fascist approaches that evolve in the social and political milieu around his pupils. Moncho, a sensitive and bright child, is inspired by the teacher to explore nature and becomes familiar with birds and butterflies. In a symbolic scene, the teacher gives him an apple, and thus tempts him to doubt religion and social and political norms. Freire would probably approve with Don Gregorio's attempts to empower his students and encourage them to adopt social and cultural criticism.

Towards the end of the film, the political extremism intensifies. Conservative nationalist forces gain power and, in the final scene, remove the teacher to be executed. Moncho, the beloved pupil, joins the children of the villages in throwing stones at the truck that transports Don Gregorio and the other political prisoners while cursing the prisoners, for being "communists," "anarchists," and "traitors."

Here too, the final scene is open to interpretation, because Moncho mixes into his shouting of political words the names of birds and butterflies that he had learnt from the teacher. Does this mean that he has internalized the teacher's values after all? Or perhaps he is merely confused by all these Latin words and is an innocent victim of adult conflicts that are forced upon him? Different viewers react differently to this scene, but one message people commonly find in it is that teachers cannot educate children towards ideological directions that differ from those of their societies' dominant forces; whoever tries to do so risks his life.

Indeed, other pedagogical tragedies addressing teachers' attempts to promote social change also end with the death of pupils, teachers, or both (e.g., La Journe de la Joupe [28]). All these movies may deliver to beginning teachers a threatening message about their limited ability to promote moral and political changes and about the price that might be paid for seeking change. After watching movies of this genre with beginner teachers, it is important to hold an open discussion. These films may be helpful in analyzing the complexity of educational processes, but facilitators should raise the viewers' awareness regarding the elusive but present conservative approaches in these movies, in order to prevent a subconscious absorption of the fear of change. We must make sure that the movies do not discourage teachers from trying to educate towards values they believe in despite contradictory social norms - or perhaps even because of them. 


\section{Pedagogic Tales and Legends}

In contrast, many pedagogical movies have a happy ending. A teacher may, for example, help a pupil to discover a talent and to develop it against all odds. In the film Billy Eliot [24], Billy, who grows up in a poor family in a British mining town, crosses cultural and social barriers to become a dancer - ultimately even the star of a London ballet troupe. In the ending scene, Billy performs Swan Lake. His swan costume elicits associations of The Ugly Duckling and implies that such a cultural transformation takes place only in fairy tales. The film not only questions whether such personal transformation is possible, but also highlights the barriers to social mobility and the impermeability of social and economic divides, shedding doubt regarding whether a talented individual can overcome all these gaps to attain personal success.

Freire might make use of this film to discuss the teacher's mission in leading students in the journey out of their weakened status, but he may also critique the movie as achieving the opposite result: while pleasing the viewers with the personal success of one imaginary child in the movie, we are placated from raising the real questions about the social powers. According to this interpretation, the teacher may be seen as another tool used by conservative and capitalist powers to instill an illusion of change, while avoiding any real change that may be attainable only through a political revolution.

The French movie Les Choristes[25] offers another example of the miraculous change that can happen through art and music. Mr. Clement Mathieu is a supervisor at a boarding school for children and adolescents with disciplinary problems including disobedience and violence. Mathieu introduces the boys to classical music and founds a choir. As they sing like angels, their attitudes and behavior improve, as does the general quality of their lives. Morange, the introvert and misbehaving child, cannot read music at the beginning, but is discovered as a wonder voice and grows up to be a world-known conductor. In addition, a few miraculous processes occur in the film: the dark school building is set on fire, the oppressive institution is closed, and the mean headmaster is fired. On top of all this, one fantasy that probably crosses every teacher's mind at least once in her career - the fantasy to adopt a parentless pupil as her own son - is fulfilled. Indeed, as Mathieu leaves the school, he takes Pepino, the little orphan that waited every Saturday at the gate for his dead father to pick him up; Pepino gets a new father and the childless teacher wins a son.

The movie provides an enjoyable experience of fulfillment of pedagogical and personal fantasies, accompanied with wonderful music that opens our heart; but ultimately, we might be left with a disturbing feeling that these miracles will not occur in our own classrooms, because such things 'only happen in the movies.'

Notably, the feeling of fantasy is not just a subjective interpretation. Through various hints, the movie declares itself to be nonrealistic. First, the film starts with a picture of an opening book - a clue that what we are watching is a tale.
Second, the sound-track does not fit what we see. One scene shows a group of children, untrained in music, and singing without instrumental accompaniment in an ordinary classroom. The scene's sound track, in contrast, is the professional singing of a choir, replete with an orchestra, which was surly recorded in a well-equipped studio or a concert hall with ideal acoustic conditions. A viewer who is aware of the cinematic symbolism would notice the 'fraud,' but even an innocent viewer would sense that the scene is somehow nonrealistic.

We can interpret this fantasy in various ways. A fantasy can offer a horizon that drives and motivates teachers and people in general to act; alternately, it can be an illusion - a fata morgana. We could interpret the difference between the pictures we see and the sounds we hear as the gap between the present situation in the classroom and the future vision of the teacher (whose achievement comprises his professional purpose). Under the latter interpretation, the movie can be considered an inspiration for transformative teaching. Under the former interpretation, it may discourage teachers with the notion that change is not really possible -especially in their poorly equipped classrooms with inadequate acoustics.

The unrealistic transformation that teachers perform in their students in the movies provides a cause for critique of the lack of authenticity and reliability of the plot, as emerges from a review [4] about the British movie, To Sir with Love: "Since he never gets beyond the introductory sentences, we have to accept a lot on faith. The pretense that these milky aphorisms will make gentlemen out of hoodlums may be what suburban audiences want to hear - but can even they believe it?... The music isn't bad but little else sounds genuine" (p. 50). Nevertheless, even movies that open with the declaration: "based on a true story" (i.e., Freedom Writers[27], the Ron Clark Story[26], McFarland[32]) do not really seem to impress the viewers as being realistic, because of the cinematic choices that must be made in order to fit a long educational process into 90 minutes. Moreover, educational processes are always complex, as Schwab had shown us; these processes are often simplified in movies so that they can be presented through a limited set of characters and events. Finally, moreover, teachers' transformative work tends to seem unrealistic in movies because certain aspects of the educational change are invisible to the eye, and movies must exaggerate them in order to make them visible on screen.

Here too, critical viewing is advisable. The discussion should first deal with revealing and consciously recognizing the sense of fantasy delivered by these movies. Freire's advice about active and interactive reading may help disclose the hidden oppressive effect of these cinematic texts. Then, we can progress by asking what parts of the educational success the films depict may actually be possible in real classrooms, with real pupils. In such discussions, I found that viewers indeed find motives to inspire them in their educational work, despite the clear differences between their real classrooms and those on the screen. 


\section{Pedagogical Action Movies}

The group of movies about teachers that I call 'action movies' includes films that show difficulties and failures alongside achievements and successes. The basic plot of many of these movies is similar. The film usually opens with a difficult encounter between the teacher (who is full of good intentions)and a group of pupils (who are indifferent and bored, or wild and violent, and have no motivation to study and no respect for their teachers). Between the teacher and the class there is a wide gap in language and residences area, and usually a difference in skin color. The teacher's attempts to make the pupils learn yield no results, until a breaking point in which the teacher realizes she must change her methods of teaching in order to 'get to' the pupils.

At this point the teacher deserts the books, curriculum, or examinations; changes the subjects learnt; and creates a different interaction with the pupils that is nonacademic and informal. Following this breaking point, her relationship with the students and the students' willingness to cooperate improves. By the end of the movie, a significant transformation has taken place in the students' attitudes, behavior, academic achievements, and even physical appearance.

This line of plot is repeated in so many movies: Freedom Writers[27], Dangerous Minds[21], The Ron Clark Story[26], and others.

The movie To Sir with Love [1] may be considered the pioneer of this genre. Here, the breaking point of the teacher, Mr. Thackeray, includes throwing the books to the garbage bin, deserting the curricular subject, and starting an open conversation with the class about "life, survival, rebellion, sex, marriage..." i.e., issues that are relevant to students and problems they are worried about in their daily struggles. In this conversation, the teacher also declares that from that moment on he is going to treat the pupils as adults and encourage them to take responsibility for their social reality: "it is your duty to change the world."

This scene shows exactly what Freire would have expected the liberator teacher to do. Mr. Thackeray replaces frontal teaching with dialogic pedagogy and also practices 'situated pedagogy, 'whereby real life is discussed and analyzed in class. Schwab too may have found this movie to encourage teachers to practice their autonomy in class and to apply discretion based on their pupils' reactions. On the other hand, Schwab may have had some reservations, as I present below.

Furthermore, in this movie, as in many others, the teacher's decision to desert the curriculum involves a resolve to leave the classroom physically and go outside. As a result of his new pedagogy, Mr. Thackeray's class decides to go to the museum, and the pupils discover that art and culture can be fun and are closer to them than they ever imagined. In other movies, the teacher takes them out to a restaurant (Freedom Writers [27]), to the amusement park, or to the pupils' homes (Dangerous Minds [21]).

Another motive that is repeated in these films is the conflict between the teacher and the school management; the teacher works without any support from colleagues or from the people in charge and makes changes at the risk of being fired, while the headmaster always objects to all the educational initiatives or projects that the teacher is trying to execute. Indeed, Schwab likely would have disapproved of the teacher's acting as a lonely knight, neglecting teamwork, and hurting the balance between different aspects of the educational process that Schwab highly regards. In addition, Schwab would have probably found these teachers' decisions to quit the curriculum altogether to be too radical and to greatly surpass the autonomous interpretation opportunities within the system.

I agree with this critique and consider quitting the curriculum and leaving the school system in order to practice a meaningful education to be a problematic decision. As we saw, a few films repeat the motive of throwing away or destroying books; the formal curriculum is presented as irrelevant to the student's lives. The message we get is that teachers must quit teaching in order to start educating. I question the alleged dichotomy of 'teaching' and 'educating.' I find problematic the message that allegedly, meaningful educational work cannot be conducted through the help of books and through the disciplines currently existing within the curriculum.

Indeed, teachers should engage in a critical viewing of these films. The fields that we teach - mathematics, language, natural sciences, social sciences, history, literature, philosophy, and others are rich with interesting issues and meaningful texts, which could be taught in a mode that is relevant, intriguing, and even mind-blowing. I seek to challenge the populist idea that in order to be relevant, the teacher must transcend the classroom or compromise the academic studies and to give up on strict standards of intellectual work. Instead, I turn to Schulman's emphasis on teachers' special ability, which he defined as 'pedagogic content knowledge.' [15] While acknowledging this ability, Schulman responds to the popular mistakes and says: "those who know - do, and those who know and understand teach."

As a philosophy teacher in high school, I indeed experience the possibility of teaching a theoretical discipline, which is taught only inside class rooms and through texts and books, with systematic and strict methods of thought. I find that I am able to instill independent thinking and a critical approach to life, and to treat issues that are relevant to the student's lives' and may even promote transformation in their views and approaches.

In this regard, I find support in the writings of both scholars discussed above. As noted, Freire stressed that the dialogic pedagogy is not 'free education' and that it includes academic rigor, hard work, and systematic reading of texts([6] pp. 4-6, 10-11). Moreover, Freire and other thinkers from the 'Radical Pedagogy' school advice teachers to work within public schools and to make small, gradual changes that encourage students to think critically about their social and political reality and thereby to yield cautious, local 
transformations -as opposed to a total revolution in the school system([6] pp. 180).

A similar emphasis may be found in Schwab's words when he explains his notion of teachers' autonomy as not necessarily a rebellious type of freedom, but rather a work of constant interpretation ([13] p.247). Schwab also notes that processes of change in education, like in other practical fields such as medicine and law, can only be undertaken cautiously and gradually in order to maintain the system's ability to function, and the stability of the child's educational process ([11] p. 112).

Thus, as oppose to the dramatic steps that the teachers in the movies make to yield a magnificent revolution, both Freire and Schwab promote a more modest pedagogy that recognizes the teacher's freedom to design the curriculum and enhances the students' ability to change from within classrooms, while respecting existing curricula (Schwab) and academic books (Freire).

To conclude, let us reflect again on 'pedagogic action movies' and look at the dual messages they transmit. On the apparent level, these movies present the teacher as a super-hero -a brave free thinker with unstoppable energy mobilized for the good of his pupils. This hero may be thought of as a source of inspiration and motivation for young teachers. On an elusive level, however, such films send the teacher a frightening message, saying that if you are not a 'super-man,' you better accept the norms of school, because any change will include a lonely battle and potential personal risks. These films' hidden message - a discouraging one for teachers - is that good teaching is a dangerous adventure, which cannot take place within the normal framework of the schoolteacher's work. A critical discussion may bring these messages to the surface to 'immunize' beginner teachers against any subconscious discouragement they may produce.

\section{Conclusions}

Freire and Schwab teach as that teachers are autonomous and that they can lead processes of change in the school system as well as in society. Indeed, films about teachers can inspire teachers to dare to use the freedom they have in class and to be promoters of change. On the other hand, the same movies may also instill in teachers doubts regarding their own competence to create change and fears of the outcomes of such a change. In order to utilize films about teaching as tools to address teachers' self-image, fears, and apprehensions, the facilitator should provide a guided and critical viewing that leaves room for a rich and complex interpretation: one that raises the teachers' awareness to the ambivalent messages present in society and expressed in movies about the teacher's role. Through such critical viewings and candid discussion, Freire and Schwab's empowering notions regarding teachers' autonomy and transformative roles can be vividly presented and can inspire teachers while also tackling the common stereotypes, misconceptions, unrealistic expectations, and potential conflicts that surround the teaching profession.

\section{REFERENCES}

[1] Ãngeles Vilches Norat et al. (2016), "Ecopedagogy: A Movement between Critical Dialogue and Complexity: Proposal for a Categories System", Journal of Education for Sustainable Development, 2016, vol. 10, issue 1, pp. 178-195

[2] Bound, H.(2015) "Problematizing workplace learning" in: Bound \& Rushbrook (Eds.) Towards A New Understanding of Workplace Learning: The Context of Singapore, Institute for Adult Learning, Singapore. pp 1-16

[3] Dewey, J. (1916), Democracy and education: an introduction to the philosophy of education, Gutenberg project 2008.

[4] Farber, S., (1968) Review: TO SIR, WITH LOVE by James Clavell... Film Quarterly, Vol. 21 No. 2, WINTER, 1967-1968(pp. 50-52)

[5] Freire, P. (1968) Pedagogy of the Oppressed. New York: Continuum, 2007.

[6] Freire, p. \& Shor, I. (1987), A pedagogy for liberation: dialogues on transforming education: South Hadley, MA: Bergin and Garvey.

[7] Freire, P. (1975). Concientization. Geneva, World Council of Churches.

[8] Garcia, L.G. (2015), "Empowering Students through Creative Resistance: Art based Critical Pedagogy in the Immigrant Experience" , Diálogo, Volume 18, Number 2, Fall 2015 pp. 139-149 | 10.1353/dlg.2015.0037

[9] Roby, T. W., (2008) "How Joe Schwab Thinks - A Review of The Practical 1 after 40 Years", Journal of Curriculum Theaorizing, vol 24/1 pp. 85-89.

[10] Rodriguez, M. (2015), Theater for social change as a method to empower Mexican youth", submitted for Master of Arts in the Department of Theatre \& Dance, University of Central Missouri.

[11] Schwab, J.J., (1969) "The Practical: a Language for Curriculum", in: Flinders, D.J., \& Thornton, S.J. (Eds.) The Curriculum Studies Reader, (2nd ed), New-York: Routledge 2004, pp 103-118.

[12] Schwab, J.J, (1971) "The Practical: Arts of Eclectic", The School Review, Vol. 79, No. 4. Aug., 1971, pp. 493-542.

[13] Schwab, J.J (1973) "The Practical 3: Translation into Curriculum", The School Review, Vol. 81, No. 4. Aug., 1973, pp. 501-522.

[14] Schwab, J.J (1983) The Practical 4: Something for Curriculum Professors to Do", Curriculum Inquiry, Vol. 13, No. 3 (autumn, 1983), pp. 239-265.

[15] Schulman, L. S. (1986). Those who understand: Knowledge growth in teaching Educational Researcher, 15(2), 4- 31.

[16] Spaaij, R. (2015) Refugee youth, belonging and community sport Leisure Studies, Volume 34, Issue 3. 
[17] Villacañas de Castro, L. C. (2016), The Pedagogical Solution: Freire's Critical Pedagogy and Social Democracy, In: Villacañas de Castro, L. CCritical Pedagogy and Marx, Vygotsky and Freire, UK: Palgrave Macmillan, ch. 3

Film:

[18] To Sir with Love, James Clavell, England, 1967.

[19] Educating Rita, Lewis Gilbert, England, 1983.

[20] Dead Poet Society, Peter Weir, 1989.

[21] Dangerous Mind John N. Smith, USA, 1995.

[22] Good Will Hunting, Gus Van Sant, USA, 1997.
[23] La lengua de las mariposas, José Luis Cuerda, Spain, 1999.

[24] Billy Eliot Steven Daldry, England, 2000.

[25] Les Choristes, Christopher Bartier, France, 2004.

[26] The Ron Clark Story, Randa Haines, USA, 2006.

[27] FreedomWriters, Richard La Graveness, USA, 2007

[28] La Journee de la jupe, Jean-Paul Lilienfeld, France, 2009.

[29] American Teacher, Vanessa Roth and Brian McGinnis, USA, 2011.

[30] Teach, Davis Guggenheim, USA 2013.

[31] Whiplash Damien Chazelle, USA, 2014.

[32] McFarland, Niki Caro USA 2015. 